
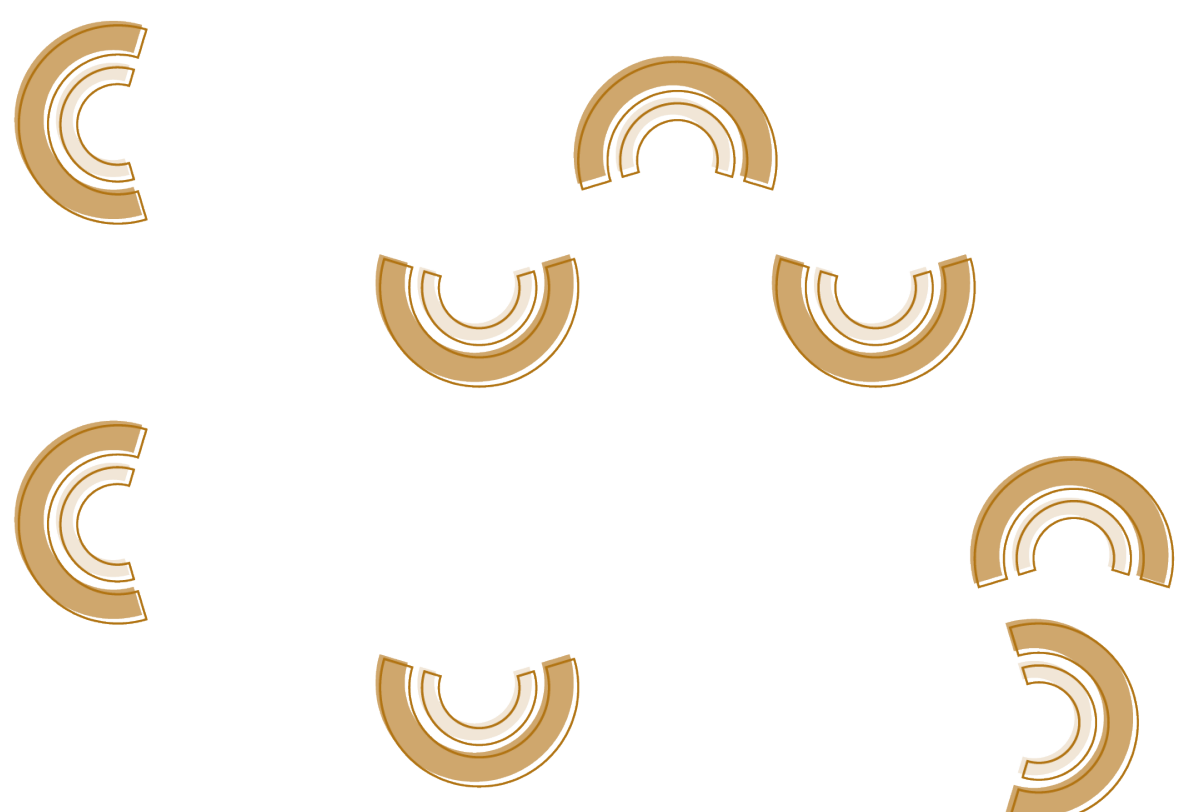

Dossiê Dramaturgia da DANÇA

\title{
CAZADOR DE MARIPOSAS ${ }^{1}$
}

\section{Patricia Cardona}

Educadora e pesquisadora internacional de dança, com diversos projetos realizados e livros publicados. Integra desde 1990 o Centro Nacional de Investigación, Documentación e Información de la Danza José Limón (CENIDI) na Cidade de México, México. 


\section{LA DRAMATURGIA DEL BAILARÍN}

¿Se puede utilizar el término dramaturgia en la danza? Entendido como "acción escénica", desde luego. Los coreógrafos de todos los tiempos estructuran una totalidad escénica que podría llamarse dramaturgia dinámica, es decir, una serie de sucesos temáticos o abstractos entrelazados, alrededor de los cuales se definen y condiciona el manejo del espacio, el tiempo, los desplazamientos de los cuerpos, las cualidades de la energía, la luz, el vestuario y la música. Sin embargo, a esto se le ha llamado coreografía (de choreia, en griego) porque predomina en la práctica común el concepto de diseño espacial por medio de cuerpos en movimiento, en contraste con la dramaturgia teatral, entendida general y limitadamente como literatura dramática, narración o anécdota. Esto, en danza, equivaldría al libreto.

La costumbre y el lugar común seguirá remitiéndonos al término coreografía cuando hablamos de movimientos que articulan los coreógrafos en una estructura dinámica, narrativa o no, realista o metafórica. Sin embargo, jamás se ha empleado un término para precisar, de manera directa, la responsabilidad del bailarín co-creador como traductor de las ideas, propósitos y lenguaje del coreógrafo. A esto se le llama simplemente "interpretar", término, para mi gusto, demasiado vago. Significa todo y nada.

Trasladar a la danza el concepto de dramaturgia, así como el de bailarín/ actor, equivale a encender una luz roja. Nos obliga a pensar en un tipo de peripecia mental que difícilmente se cultiva en el bailarín. Conocemos básicamente la peripecia dinámica que solemos llamar coreografía.

Desde el punto de vista de la dramaturgia del bailarín/actor, interpretar implica poner en marcha este tipo de peripecia mental para darle sentido y

1 N.E. Capítulo do livro Dramaturgia del Bailarín. Un estudio sobre la naturaleza de la comunicación escénica y la percepción del espectador. (Ciudad de México: CONACULTAINBA, 2000), p. 43-54. Material cedido pela autora. 
precisión a la peripecia dinámica. Requiere de una preparación previa para acceder al lenguaje expresivo del coreógrafo, del por qué y para qué de las acciones que se han de materializar en el cuerpo del bailarín/actor. Implica una apropiación muy personal del sentido de ese lenguaje. Implica humanizar aquello que el intérprete sólo recibe como forma (partitura de movimientos) o como análisis de personajes y situaciones. El bailarín encarna, revitaliza, hace verosímil la forma aprendida. Estructura un significado. Esto es hacer dramaturgia. Implica el regreso a la persona, el sujeto de la danza.

La necesidad de entrenar al bailarín no sólo en la peripecia dinámica (lo visible), sino también en la peripecia mental (lo invisible) se ha convertido en un clamor en ciertos sectores de la danza.

El antecedente más inmediato se dio en los años ochenta: los bailarines se propusieron enfrentar sin prejuicios ni limitaciones una dificultad apenas planteada en los años setenta, es decir, hacer de la energía emocional un lenguaje visible, elocuente.

Mundialmente, la danza/teatro brotó en los centros cosmopolitas como los hongos en las montañas húmedas del planeta. Prendió porque en la atmósfera vibraba la necesidad de sacar explosivamente las visiones apocalípticas de la época. Como espectadores, vibrábamos al unísono con los bailarines.

Aunque la danza/teatro nunca se definió como estilo, oficio o tarea escénica, movilizaba energía a raudales. Había el compromiso del coreógrafo con la sociedad y consigo mismo. El hecho de sobrevivir cotidianamente se convirtió en lenguaje coreográfico.

Pero mucho de lo plasmado era intuitivo. Faltaba la ciencia de la construcción escénica en la mayor parte de los jóvenes creadores. Sobraba intención, motivación. Y esto es lo que interesa a la danza/teatro: el por qué y para qué del movimiento. Éste era el momento perfecto para investigar la manera de acercar la danza al teatro y viceversa. Volver a los orígenes.

En los años noventa, cuando la danza/teatro deja de serle útil a una gran mayoría de coreógrafos porque como plataforma de grito, aullido y rebeldía había agotado todas sus posibilidades (precisamente por carecer de una base teórica y práctica que le diera consistencia), algunos empiezan a preguntarse cuál es la ciencia que puede integrar la emoción con el movimiento, la idea con la acción física, la historia con la congruencia orgánica, la comunicación con la metáfora poética. No había otro recurso más que el de la dramaturgia, no literaria, sino de montaje escénico. Nació paralelamente la noción de la dramaturgia del bailarín, complementaria a la planeación de los sucesos esenciales dentro de una unidad, que vendría siendo la dramaturgia del coreógrafo. 
Hay corrientes artísticas que exploran exclusivamente las formas (George Balanchine y Merce Cunningham). Encontrarles el sentido depende del grado de perfección y placer con que se desenvuelven los bailarines, vehículos de su propia y elocuente humanidad. En la danza temática o dramatúrgica, por el contrario, el sentido lo encontramos en la claridad de un lenguaje estructurado a partir de estímulos mentales que justifican plenamente cada una de las acciones, impregnándolas de significado.

Muchos coreógrafos que elaboran su dramaturgia previamente al montaje consideran que la "acción" es lenguaje suficiente para comunicarse con el bailarín. Se ahorran el "trabajo de mesa" o análisis de contenidos. Si la comprensión del bailarín/actor es errónea, desde el punto de vista del autor, es porque el movimiento no es suficientemente preciso aún. Digamos que ésta es una manera en la que el coreógrafo pone a prueba su propia creatividad.

Y, para el bailarín, ésta es una forma de hacer dramaturgia por la vía de la acción inmediata y no de la reflexión previa al montaje. Porque es el movimiento el que despierta memorias, contenidos y asociaciones que luego se organizan como imágenes mentales.

La dramaturgia del bailarín tiene un amplio margen de creación siempre y cuando no se convierta en un espacio imaginario ajeno al piso común del resto del grupo u objetivo de la coreografía. Guillermina Bravo admite que el misterio del "metabolismo interno" de una obra se da cuando la expresión del bailarín se funde con la del coreógrafo.

\section{ENTONCES SE CONVIERTE EN BAILARÍN/ACTOR}

El bailarín/actor "abre" el espacio interno y crea el mundo subjetivo del personaje, en una obra tanto formal como narrativa, nos dirá Luis de Tavira. Lo organiza en estímulos articulados de manera secuencial. El bailarín/actor reacciona ante los estímulos. Cuando el ejecutante se mecaniza, a lo largo de muchas funciones, ¿qué pasa con el aspecto vital de la estimulación en la dramaturgia? ¿Es el estímulo efectivo?

La tarea del bailarín/actor es propiciar la peripecia mental y dinámica del personaje. Articula los estímulos invisibles, imaginarios, no las reacciones visibles. Éstas nacen libre y naturalmente y pueden ser distintas cada noche aunque esté perfectamente trazada y fijada la partitura dinámica. Cuando se plantea muy bien la relación entre estímulo y estímulo, de principio a fin, se potencia la energía creadora del bailarín/actor. ¿Qué pasa con la forma fija de la danza dentro de este contexto? Se renueva en cada función.

La esencia de la interpretación está en la estimulación imaginaria, dirá De Tavira, y no en la reacción como acción fija. Hay montajes en los que se 
sacrifica lo dramático (lo estructurado) por la vitalidad, y la partitura dinámica se vuelve caótica. También sucede lo contrario. Se sacrifica la vitalidad en aras de la literatura dramática (libreto) o de la forma estética, y la estimulación pierde su fuego.

Sea una estructura poética/simbólica, geométrica/formal o realista/narrativa, finalmente es la estimulación estructurada (peripecia mental) del bailarín/ actor la que le da sentido, sangre y nervio a la forma imaginada por el coreógrafo. Es preciso aclarar que la danza no necesariamente sigue una lógica racional, sino más bien orgánica de la imaginación. Por ello se habla metafóricamente sobre el movimiento, se descubren sutilezas ocultas y el bailarín se humaniza.

Salvo las obras tradicionales del ballet clásico y algunas contemporáneas realistas, las coreografías casi nunca cuentan historias. Más bien parten de motivaciones que son imágenes metafóricas. La metáfora encierra el nudo de la mecánica del movimiento, nos dirá Natsu Nakajima. Contiene la energía física y psíquica del significado esencial. Y esto requiere de mucha precisión y atención. Por ello el bailarín sigue una imagen, la transforma y persigue en su vuelo dinámico como si fuera cazador de mariposas. De ella depende la claridad de la coreografía.

Esta dramaturgia de los estímulos mentales le permite al intérprete aferrarse a la imagen poética, y, como expresa Natsu Nakajima, "intoxicarse de ella", dejarse atravesar por todas las fuerzas que despierta en el inconsciente y expresarla escénicamente.

\section{HISTORIA DE CONTRARIOS}

Aún hoy podemos ver cómo el repertorio tradicional del ballet clásico se estructura alrededor de una dramaturgia narrativa con base en un libreto. Es el género más apegado a este concepto. Desde Noverre, coreógrafo francés del siglo XVIII, gran impugnador de la mecanización del bailarín, creador de los "ballets de acción", ya se hablaba de la anécdota como eje de los materiales escénicos a integrar.

La humanización de la danza, de Lin Durán, resume de manera explícita el proceso mediante el cual la danza pasó del libreto a la dramaturgia. La estructuración de imágenes poéticas, dice, apareció con las bailarinas modernas de principios del siglo XX. Fueron seducidas por los temas de actualidad y armaron sus coreografías a partir de la música y situaciones dramáticas subjetivas, haciendo a un lado el libreto. Con Isadora Duncan se inicia un nuevo concepto de la danza y de la vida al establecer una profunda unidad entre ambas. Vio en Nietzsche al primer filósofo de la danza por su defensa del hombre como unidad indisoluble: cuerpo/mente/espíritu. 
La aparición de la danza moderna, con vigencia hasta los años cincuenta, marcó la ruptura definitiva con el pasado. Para Mary Wigman, pionera alemana de la primera mitad de siglo, cualquier estímulo visual, auditivo y sobre todo emocional se convertía en una motivación creadora. Hizo decenas de solos en los que la peripecia dinámica iba acompañada de la peripecia mental. Mary Wigman expresa que en la obra para solista el bailarín establece un diálogo consigo mismo y con una "pareja invisible". Es una "relación irreal" que funciona como un "punto de tensión" en el espacio y que la obliga a detenerse, "como si hubiera una fuerza que jugara conmigo y a la que yo quisiera penetrar, sentir, vencer. Es decir, pregunta y respuesta pero expresadas por mí misma y en el proceso de una metamorfosis" (DURÁN, 1993, p. 24). ${ }^{2}$

Es éste un extraordinario ejemplo de la dramaturgia del bailarín. Enciende el fuego de la vida en el escenario, al mismo tiempo que permite resolver los tres catalizadores básicos de la atención en el espectador: conflicto, contraste y transformación.

En otra parte del texto, Wigman dice: "Los tres elementos que dan vida a la danza son tiempo, energía y espacio. De esta triada el espacio es el ámbito de la actividad del bailarín. Le pertenece porque es él quien lo crea y le da vida en la dimensión imaginaria, sensible..." (Ibíd., p. 40). Nos habla del espacio simbólico, escenario de los estímulos mentales a partir de los cuales se genera el lenguaje vital de la danza.

Lin Durán resume igualmente la preocupación fundamental de Doris Humphrey, quien, una vez instalada en el Nueva York de los años veinte, desarrolló la individualidad del bailarín. Desde entonces se quejaba de no encontrar al co- creador necesario en el proceso del montaje coreográfico. "La mayoría de los alumnos, especialmente las mujeres, son borregos dóciles a quienes les encanta tener un amo. Los más difíciles son aquellos que llevan años siguiendo un entrenamiento académico en el sentido de que se les ha dicho qué hacer exactamente cada minuto" (Ibíd. p. 55).

Para Doris Humphrey la palabra "motivación" fue el eje articulador de toda acción. Creyó en el movimiento como resultado de un propósito. Un gesto no debe aparecer mientras no haya una razón que lo justifique, decía.

Es esta "razón" la que tiene que generar precisamente el bailarín. No basta con la "razón" impuesta por el coreógrafo.

Más allá de Mary Wigman y Doris Humphrey, a Martha Graham se le conoce por haber elaborado la más refinada dramaturgia poética. Su gran inteligencia consistió en descubrir que el arte moderno devela las realidades íntimas ocultas detrás de los símbolos convencionales (Ibíd. p. 63).
2 N.E. Durán, Lin. La humanización de la danza. México: INBA, 1993. 
Consideró que la enseñanza parcializada de Occidente -primero los músculos y luego las emociones - nunca producirá un ser humano completo. Estaba convencida de que el concepto puritano de la vida ha ignorado el hecho de que el sistema nervioso, la mente y el resto del cuerpo son una unidad y que el arte no puede experimentarse más que como una totalidad del ser.

Reconocía que el movimiento corporal, dirigido con autenticidad, es el "medio artístico más poderosamente peligroso que se conoce". Habla el instrumento básico, el cuerpo, espejo intuitivo, inevitable de la verdadera condición del individuo.

Martha Graham creó a partir de estructuras dramáticas y usó todos los recursos del teatro como los de las exploraciones científicas de Freud y Jung para conmover a su público. Durante años los conciertos de danza se consideraron producciones teatrales, o "teatro de danza".

Sin duda, su arte no podía ser interpretado por un bailarín mecanizado. Cuando actualmente vemos la obra de Graham sin la previa preparación dramatúrgica del bailarín, su lenguaje se despersonaliza y cae en la neutralidad virtuosa de la danza académica, sin consecuencia para el espectador.

La carga dramática exigida por Graham dio pie a la rebelión artística de fines de los años cuarenta hasta los sesenta, iniciada por Merce Cunningham. Renegó de la teatralidad, de la técnica extenuante, de los contenidos míticos, la emocionalidad, el psicologismo y la solemnidad de la obra de Graham. Pero el cuerpo no se puede desprender de sus contenidos, de su biografía e idiosincrasia, en síntesis, de su condición humana. En algún gesto o tensión dinámica, en alguna mirada o desplazamiento, se revela la dramaturgia espontánea, el fuego de la vida. En este sentido, incluso Merce Cunningham, desde su primera rebeldía, fue humano, demasiado humano.

\section{TODO ES DANZA}

La aparición de Merce Cunningham en el escenario del cambio sembró las semillas para la danza posmoderna o formalista. Su filosofía fue contundente: cualquier tipo de movimiento puede ser material válido para hacer danza. Cualquier proceso se justifica como método creativo. Toda parte del cuerpo puede ser utilizada para la creación coreográfica. La música, vestuario, decorado, iluminación y danza tienen su lógica particular. Todo bailarín puede ser solista. Cualquier espacio es un escenario posible para la danza, que puede ser sobre cualquier tema, pero sobre todo acerca del cuerpo y su movimiento, empezando por la acción de caminar.

Terpshichore in Sneakers, de Sally Banes, explica cómo la revolución iniciada por Cunningham y las siguientes generaciones de coreógrafos sostuvieron 
una convicción: el movimiento es significativo por sí mismo³. No requiere de la articulación de estímulos mentales en una estructura causal, predeterminada por el coreógrafo y el bailarín. Cada danza, por tanto, debe ser distintiva sólo por las cualidades de la energía y sus formas. Más que una estructura unitaria, propusieron una "variedad de experiencias" — visuales, auditivas y kinéticasante las cuales el espectador tiene la libertad de elegir e interpretar a su manera, o simplemente absorber sin que lo conduzca a ningún estado o conclusión en particular. Acabaron con aquella "cómoda situación y predictibilidad del movimiento" que se rige por una estructura musical, anecdótica o psicológica.

Los seguidores de Cunningham hablan de una lógica física que incluye el azar para determinar la secuencia de los movimientos de una frase coreográfica, el número de bailarines participantes o las zonas del cuerpo que serán activadas. El resultado de esta metodología, según algunos críticos, es la flexibilidad, el cambio permanente y el placer del "drama idiosincrático de la individualidad".

Todos estos principios fueron llevados hasta sus últimas consecuencias. Los coreógrafos posmodernos se alimentaron de happenings, events neodadaístas, estructuras arbitrarias o alógicas, sucesos simultáneos, eligieron la primacía de lo visual, la introducción de objetos y situaciones de la vida cotidiana, el uso de multimedia y la tecnología a ultranza para fijar una nueva identidad frente a las madres devoradoras de la danza moderna.

Irónicamente, en los años sesenta y setenta, - convulsionados por las protestas contra la guerra de Vietnam - los temas humanos y políticos regresaron al escenario. Martha Rainer y Steve Paxton iniciaron esta ruptura con su generación. Otros prefirieron permanecer fieles a la causa del posmodernismo. Algunos, como Trisha Brown, afirmaron que la danza puede, incluso, formular o ilustrar teorías coreográficas como la noción de quietud, tiempo, espacio, gravedad o el puro placer de bailar. La filosofía detrás del quehacer dancístico puede igualmente generar una obra: ¿es un acto de construcción artesanal o un proceso de decisión y reflexión? ¿Puede el tiempo escénico ser el mismo que el tiempo de la realidad? ¿Así como se relaja el tiempo, también se relaja el cuerpo?

Sea una estructura matemática o improvisación pura o la unión de secuencias arbitrarias o fragmentos o juxtaposiciones, la forma, por igual, es tan versátil como la vida cotidiana. En los años setenta se vale demostrar al espectador el cansancio, como los errores, los peligros de la técnica y cómo se fija un movimiento. Se desmitifica la danza al grado de que desaparece la magia, incluso la técnica. Presentada en un contexto escénico adquiere, según sus protagonistas, una proyección "extracotidiana" por el simple hecho de ocupar otro espacio distinto al de la realidad.
3 N.E. Referência ao livro Terpsichore in Sneakers: Post-Modern Dance (Wesleyan University Press, 1987. 
Finalmente, Sally Banes nos conduce hasta el final de una trayectoria orgánica/ histórica: el neoexpresionismo de Meredith Monk y Kenneth King inicia otra vertiente coreográfica. Regresa la narrativa a la danza, el virtuosismo imaginativo, mental y físico en los mismos que antes proponían lo opuesto: Martha Rainer, David Gordon, Lucinda Childs, Douglas Dunn. Según un amigo muy querido, Humberto Eco ya lo había anticipado, diciendo: "debemos regresar a la anécdota, por necesidad biológica”.

\section{“CuANDO TU CUERPo SE PRENDE EN LLAMAS, AHí HAY VERDAD"}

A mediados de los años setenta también reaparece el neoexpresionismo en Europa. Requiere de intérpretes capaces de personificar y subjetivizar la danza. Pina Bausch propone su "suite de secuencias", en las que retoma la herencia de sus maestros de la Folkwangschule de Essen y específicamente Kurt Jooss, a quien se le recuerda por su montaje excepcional de La mesa verde, ejemplo extraordinario de dramaturgia mental y dinámica.

El método de Pina Bausch es peculiar. En esencia, organiza una especie de "desfile de modelos" de comportamiento cotidiano para narrar historias sueltas, pero como unidades en sí mismas. Finalmente, por el contexto en que se insertan, recuperan el lenguaje cotidiano y lo transforman en una dinámica dancística, con los ritmos, contrastes, tensiones, equilibrios, sorpresas y economía del lenguaje extracotidiano. Los bailarines son co-creadores de las obras. Buscan en su memoria personal y beben de su biografía para dar respuesta a las indicaciones de la coreógrafa. Los gestos no se homgeneizan, sino que subrayan la individualidad del bailarín/actor. Pina ha declarado en varias ocasiones que le interesan las personalidades y subjetividad de los bailarines. Exige presencia total cuando alguien "hace algo" y para ello es preciso que sepa "qué es" y "por qué" lo está haciendo.

Susanne Linke en Alemania, Carolyn Carlson, en París, Twyla Tharp y Martha Clark en Estados Unidos, andan tras lo mismo, aunque con resultados radicalmente distintos.

A lo largo de los años ochenta y noventa es notorio el giro de la coreografía mundial hacia la exacerbación de la energía vertiginosa, al límite de convertirse en acrobacia. En esta línea son pioneros Anne Teresa de Keersmaeker y Wim Vandekeybus de Bélgica, los ballets electrificantes de William Forsythe y Edouard Lock. El extremo de esta tendencia lo llegó a personificar Louise Lecavalier, figura principal de La La La Human Steps, compañía memorable del Canadá. Danza de riesgos antes inconcebibles, "cortesana" del peligro, pavorosamente virtuosa, esta tendencia se convirtió en el totalitarismo del cuerpo y su técnica. 
Interesante resulta, por otro lado, el giro que ha tomado también el ballet clásico con Jiry Kylian y Mats Ek, para mencionar sólo a dos de los coreógrafos que más han revolucionado la percepción de este género en la actualidad. Incluso clásicos de libreto como Giselle, Lago de los cisnes y Cascanueces han sido replanteados, redefinidos, resemantizados. El lenguaje tradicional ha sido "abierto", "dilatado" para permitirle la entrada a la expresión de los personajes de la vida contemporánea. Ha participado de la evolución estética vertiginosa del siglo XX y con ello ha podido asegurar su permanencia en muchos de los sectores de la vida cultural de Occidente. Al mismo tiempo, el repertorio tradicional sigue en cartelera en los principales teatros del mundo. Pero también sigue vigente la crítica que Noverre hiciera al bailarín mecanizado del siglo XVIII. En muchos casos seguimos reproduciendo los mismos vicios del pasado. La técnica y su poder de seducción fácilmente se instala en la mente del bailarín como recurso expresivo autosuficiente. Convencerlo de lo contrario ha sido lucha permanente a lo largo de tres siglos. Porque finalmente de lo que se trata en todo arte escénico es de encontrar ese punto de fusión entre la eficacia muscular y la humanidad de quien lo ejerce. La actriz británica Carran Waterfield lo ha dicho de manera inmejorable: "La verdad no se posee; sólo se puede ser verdadero. Y cuando tu cuerpo se prende en llamas, ahí hay verdad..." (WATE RFIELD, núm. 4, 1999, p. 67)4.
4 N.E. Referência ao texto "Being a Girl and Running Home", Open Page, núm. 4, marzo de 1999. Dinamarca,

Odin Teatret Forlag. 